\title{
Docetaxel-Loaded Solid Lipid Nanoparticles Suppress Breast Cancer Cells Growth with Reduced Myelosuppression Toxicity [Erratum]
}

Yuan Q, Han J, Cong W, et al. Int J Nanomed. 2014;9 (1):4829-4846.

The authors of this article have advised that there is an error in Figure 2A of this published paper. The representative photo of flow cytometry profile of $10 \mathrm{nM}$ DSN treated cells is the same as $1 \mathrm{nM}$ DSN treated cells. This is incorrect and this error was introduced during the editing process by Dovepress. The correct image for Figure 2A is included below:
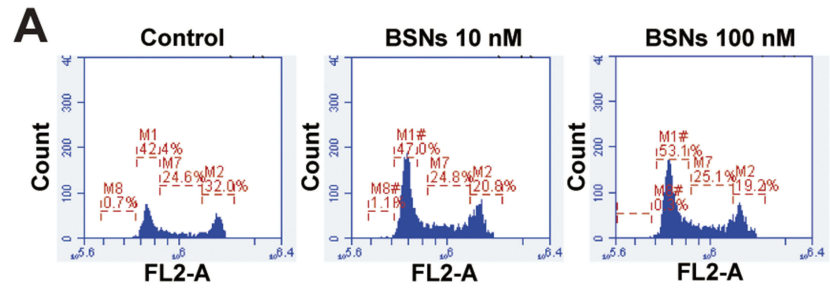

TAX $1 \mathrm{nM}$
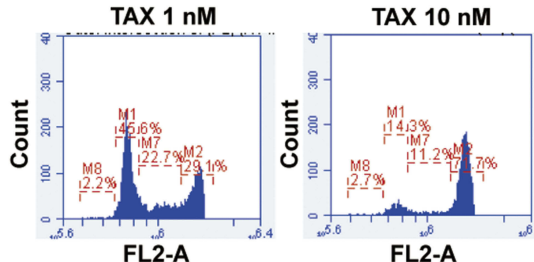

DSNs $1 \mathrm{nM}$
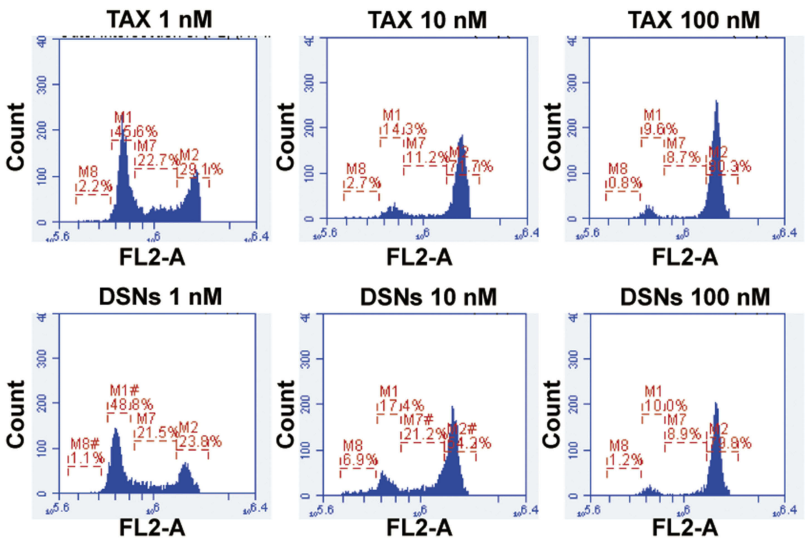

B

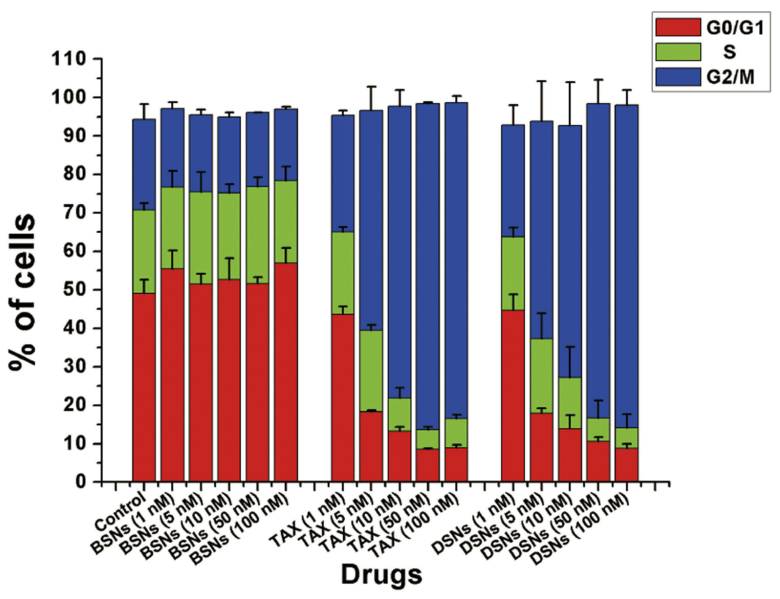

C

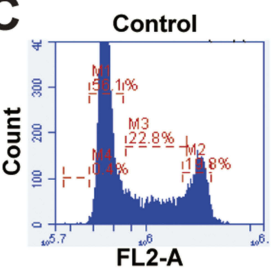

BSNs $10 \mathrm{nM}$
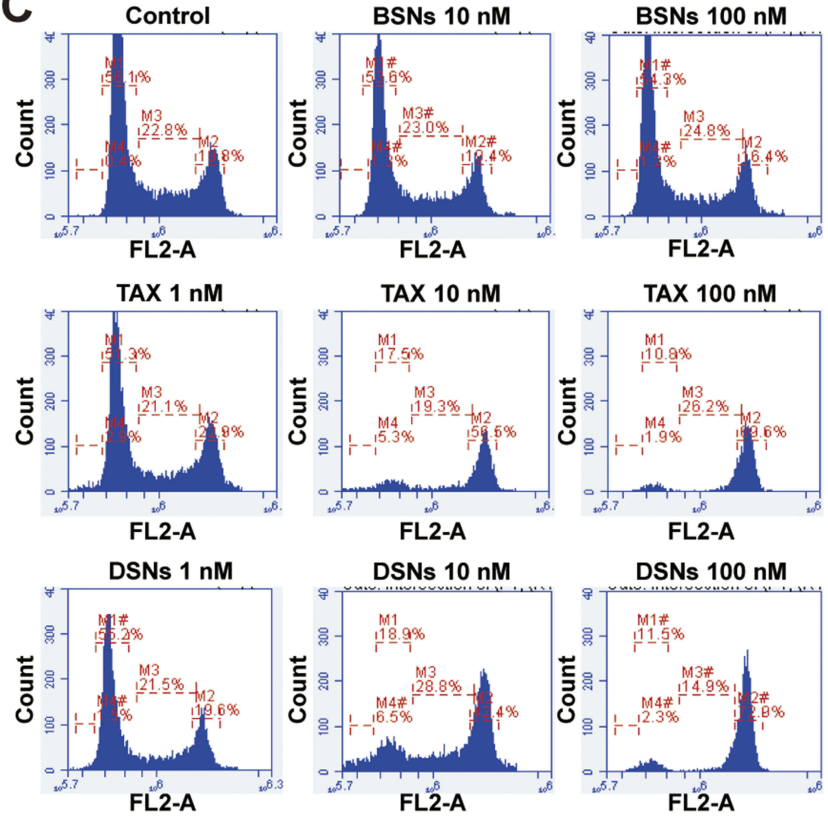

D

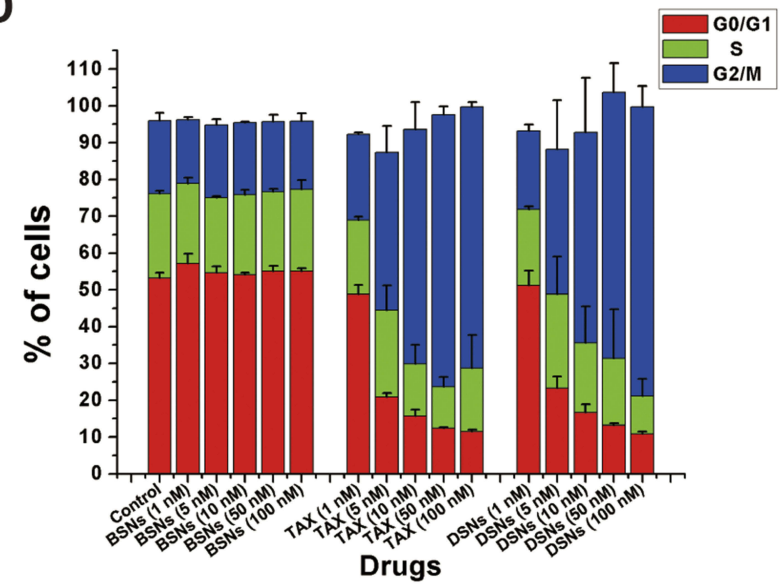




\section{Publish your work in this journal}

The International Journal of Nanomedicine is an international, peerreviewed journal focusing on the application of nanotechnology in diagnostics, therapeutics, and drug delivery systems throughout the biomedical field. This journal is indexed on PubMed Central, MedLine, CAS, SciSearch ${ }^{\mathbb{R}}$, Current Contents ${ }^{\mathbb{R}} /$ Clinical Medicine, $^{2}$
Journal Citation Reports/Science Edition, EMBase, Scopus and the Elsevier Bibliographic databases. The manuscript management system is completely online and includes a very quick and fair peer-review system, which is all easy to use. Visit http://www.dovepress.com/ testimonials.php to read real quotes from published authors.

Submit your manuscript here: https://www.dovepress.com/international-journal-of-nanomedicine-journal 